\title{
Evaluation of the Color Change of the Resins During and After the Period of Validity
}

\author{
Yuri Lobo Valle Marçal ${ }^{1}$, George Dicarlo Rolim Faria ${ }^{2}$, Frederico Nardeli Fernandes Aguiar ${ }^{2}$, \\ Laura Nobre Ferraz ${ }^{3}$, DDS, MS, PhD, Flávio Henrique Baggio Aguiar ${ }^{4}$, DDS, MS, PhD, \\ Débora Alves Nunes Leite Lima ${ }^{4}$, DDS, MS, PhD, Diogo de Azevedo Miranda ${ }^{* 5}$, DDS, MS, PhD, \\ ${ }^{1}$ Dentist of Faculty of Medical Sciences and Health of Juiz De Fora / SUPREMA \\ ${ }^{2}$ Student, Dental of Faculty of Medical Sciences and Health of Juiz De Fora / SUPREMA \\ ${ }^{3}$ Student Department of Restorative Dentistry, Operative Dentistry Area, Piracicaba Dental School, \\ University of Campinas, Piracicaba, São Paulo, Brazil \\ ${ }^{4}$ Full Professor Department of Restorative Dentistry, Operative Dentistry Area, Piracicaba Dental School, \\ University of Campinas, Piracicaba, São Paulo, Brazil \\ ${ }^{5}$ Adjunct Professor of Faculty of Medical Sciences and Health of Juiz De Fora/ SUPREMA
}

*Address for correspondence: Faculty Suprema - Dr. Diogo de Azevedo Miranda, Rua Sampaio 330/602, Granbery, Juiz de Fora, Minas Gerais 36010-360, Brazil

Received 06 May 2019;

Accepted 21 May 2019;

Published 23 May 2019

\begin{abstract}
Introduction: Composite resins are materials that have in their organic matrix different components that can change their initial state after the expiration date established by the manufacturer. Objective: to evaluate in vitro the possible color change of two composite resins used during and after the period of validity. For this, composite resins LLis color A1 and A2 will be selected, inside and outside the shelf life. Methods: For each resin (4 groups) were made ten discs $(\mathrm{n}=10)$, of $5 \mathrm{~mm} \times 2 \mathrm{~mm}$. The analyzes were carried out in an environment with lighting and temperature controlled by a single examiner. Results: The spectrophotometric test was performed using the Vita EasyShade® device in which the values of the Vitta scale and the Cie system $\mathrm{L} * \mathrm{a} * \mathrm{~b} *$ were obtained. The values of $\Delta \mathrm{E}$ were obtained by comparing the specimens of expired and non-expired resins and showed that, regardless of the color tested, the resins did not change color. Conclusion: Regardless of the color, the resins out of the shelf life showed no color difference.
\end{abstract}

Keywords: Composite Resin, color, spectrophotometer.

\section{Introduction}

The composite resin had its development with Bowen in 1956, undergoing constant transformations in order to improve its physical and mechanical properties, making it more and more acceptable for dental restoration in anterior and posterior teeth. ${ }^{[1]}$ It is known that the organic matrix of the composite resins is surrounded by by-products such as photoinitiators, resinous monomers, thinners and even pigments, which make each resin its own color for use in the most appropriate clinical situations. ${ }^{[2]}$

The introduction of new or modified dental products on the market requires the assurance that these materials can be stored for a prolonged period without any reduction in their performance, which can affect safety and efficacy. Shelf life is defined as the term or period during which a good remains for the intended use. To determine the useful life and to determine the shelf life, several parameters can be evaluated, cohesive strength (RC) such as microhardness, color stability, degree of conversion (GC), among others. ${ }^{[2,3]}$ Generally, by marketing and inspection measures by ANVISA, the expiration date is stated on the packaging and tubes of composite resins, and it is often the validity to expire before the material is totally terminated, causing, in a certain way, waste and monetary expense for the professional. ${ }^{[4]}$

Although not an acceptable practice, the use of composite resins after their expiration date is quite common; however this may affect the clinical performance of these materials, compromising dental treatment. Thus, expiration of the expiration date affects the physical and mechanical properties of the composite resins. ${ }^{[5]}$ One of the properties that is well studied with this problem is the degree of conversion; this property suggests how much monomer was converted to polymer during the photoactivation process. Considering the hypothesis that compounds with expired validity 
would have a lower degree of monomeric conversion, the insufficient monomeric conversion contributes to the absorption of several coloring substances and the presence of unconverted double carbon bonds can make the material more susceptible to the degradation reactions, resulting in reducing color stability. ${ }^{[6]}$

Thus, as there is a great variety of composite resins available for commercialization, the objective of this study was to evaluate if the resins tested would suffer some type of alteration in the initial color supplied and marketed by the manufacturer after the expiration date and to analyze whether the same resins and unmatched) would be interpreted differently through the Vita scale by spectrophotometry.

\section{Materials and Methods}

\subsection{Experimental Design}

The studied factors were composite resins LLIS (FGM) in color DA1 and DA2 (Chart 1) in two levels and the situation (inside and outside the validity) in two levels. The response variables were the color dimensions within the CIE system $\mathrm{L} * \mathrm{a} * \mathrm{~b} *$, on the top surface of each specimen. It was compared the values between the resins that were within the validity period with the resins that had expired (already to 1 year), of their respective corresponding colors.

\section{Chart 1: Composition of composite resins.}

\begin{tabular}{|l|l|}
\hline Basic Composition & Composite resin LLIS (DA1, DA2) \\
\hline Active Ingredients & $\begin{array}{l}\text { Bis-GMA monomers (Bis-Phenol A di- } \\
\text { Glycidyl Methacrylate), Bis EMA (Bis- } \\
\text { Phenol A di-Glycidyl Methacrylate } \\
\text { ethoxylate), TEGDMA (Triethylene } \\
\text { glycol dimethacrylate), } \\
\text { Camphorquinone, Co-initiator and } \\
\text { Silane. }\end{array}$ \\
\hline Inactive Ingredients & $\begin{array}{l}\text { Glass of Barium-alumina micronized } \\
\text { silicate, pigments and silica nanometer. }\end{array}$ \\
\hline
\end{tabular}

\subsection{Preparation of test specimens}

The test specimens were made by a single operator, according to ISO 4049 specifications. All specimens were made under the same conditions of temperature, illumination and relative humidity and then divided into four groups $(n=10)$, taking into account the factors under study, which are the four commercial brands of composite resins.

A polyester strip was placed on a glass plate and then a $6 \mathrm{~mm}$ diameter, $1 \mathrm{~mm}$ thick Teflon cylindrical die was placed. The resins were inserted in a single increment in the matrix and on the assembly was placed another polyester strip under pressure of an acrylic plate under a weight, so that a material compression occurred and the excess could be extravasated.

After this step, photoactivation was carried out for 40s using the Radii Cal light curing apparatus (SDI) directly against the specimen. The light intensity (mean irradiance) emitted by the photopolymerizer was $1085 \mathrm{~mW} / \mathrm{cm} 2$ previously measured by the Ecel RD-7 radiometer.

After polymerization, the specimens were removed from the matrix and then stored in dark containers, so that no external light interference could alter the quality of the photoactivation until the tests were performed.

\subsection{Evaluation by spectrophotometer}

The clinical spectrophotometer (Vita EasyShade ${ }^{\circledR}$ - Vident-Brea, CA, USA) was used in this evaluation, where three color registers were sent to each of the test specimens, in addition to the A2 reference of the Vita Classical scale. Initially, the spectrophotometer was calibrated and the reading probe was placed perpendicular and fully supported on the surface of the specimens, and the light beam was triggered from the trigger positioned on the back of the reading probe. The reading was done inside a light chamber, with ambient and controlled light. On the instrument screen, it was possible to visualize the results of the Vita Classical scale and the values of $\mathrm{L}^{*}, \mathrm{a} *$ and $\mathrm{b} *$, which were recorded in specific worksheets for further evaluation. The data of the visual comparative evaluation were qualitatively analyzed according to the percentage of correspondences observed and the agreement between examiners. ${ }^{[7]}$

The results of the spectrophotometry were objectively evaluated according to the values of hue difference $(\Delta \mathrm{E})$, obtained according to the equation proposed by the Commission Internationaled'Eclairage (CIE) 2, in 1976: $\Delta \mathrm{E}=$ $\sqrt{(L * 1 L * 2)^{2}+(a * 1 a * 2)^{2}+(b * 1 b * 2)^{2}}$ Where, L $*$ = variation of luminosity with variation from 0 to $100, \mathrm{a} *=$ red/green axis variation, $\mathrm{b} *=$ blue / yellow axis variation. In addition, spectrophotometry results were also analyzed according to the tonality of the Vita Classical reference range. ${ }^{[7]}$

\section{Results}

\subsection{Statistical analysis}

After the exploratory analysis of the data, one way analysis of variance (ANOVA) and Tukey's test were applied comparing the $\Delta \mathrm{E}$ between the four resins. Then, a t-test for a mean was applied, comparing the $\Delta \mathrm{E}$ of each resin with zero, to evaluate the color matching of the tested resins (inside and outside the shelf life). Resins with $\Delta \mathrm{E}$ closer to zero present greater similarity between the scales. The analyzes were performed in the $\mathrm{R}$ program with significance level of $5 \%$.

The two tested resins, both within the expiration date and those that were expired, did not show any color difference between them. The mean $\Delta \mathrm{E}$ (difference between expired and non-expired) was very close to zero, which shows that the color change is statistically insignificant, regardless of the color of the resin tested. ( $p<0.05$ ).

Table 1: Mean of $\Delta E$, standard deviation as a function of composite resin.

\begin{tabular}{|l|l|l|}
\hline Resina composta & Média & Desvio padrão \\
\hline Llis DA2 & 1,99 a & 0,66 \\
\hline Llis DA1 & 1,87 a & 0,77 \\
\hline
\end{tabular}

Médias seguidas de letras distintas diferem entre si $(\mathrm{p} \leq 0,05)$.

Chart 2: Color interpretation according to the spectrophotometer, using the hue / chroma pattern.

\begin{tabular}{|c|c|c|}
\hline Resin & $\begin{array}{l}\text { Color Described By } \\
\text { Brand. }\end{array}$ & Read Spectrophotometer \\
\hline \multirow{4}{*}{ Llis } & A1 & $\mathrm{A} 3,5$ \\
\hline & A1 (out of date) & $\mathrm{A} 3,5$ \\
\hline & $\mathrm{A} 2$ & A4 \\
\hline & A2 (out of date) & A4 \\
\hline
\end{tabular}




\section{Discussion}

The color difference $(\Delta \mathrm{E})$ of two objects can then be determined by comparing the differences between the respective coordinates of values for each sample ${ }^{[9,10,11]}$ In this study, the color matching of one composite resin brand in relation to the shelf life was evaluated, with two colors (DA1 and DA2) being analyzed, each color with two groups (within the validity period and after the expiration date).

According to the results obtained, the resins that obtained the greatest variance of $\Delta \mathrm{E}$ were the Llis DA2 (1.99), while the resin with the smallest variation was the Llis DA1 $(1,87)$. However, according to table 1 , statistically, these data would not differ from each other, with the $\Delta \mathrm{E}$ coming.

Within the scope of color variation $(\Delta \mathrm{E})$ the tolerance and acceptance limit was defined by Russel, Gulfraz and Moss a range of 3.3 units of variance of $\Delta \mathrm{E}$ as acceptable for samples in composite resin, whereas the Public Health Service of the States (USPHS), uses the limit of 3.7 units of $\Delta \mathrm{E}$ to determine the lack of color matching12. For the mimicking of dental structures, the clinically acceptable color difference limit is 3.7 units $\Delta \mathrm{E}$. A mean of $\Delta \mathrm{E}$, above 3.7 , becomes visible to the naked eye. ${ }^{[9,11,12,13,14]}$

Thus, with the results obtained by the spectrophotometer, it can be stated that the resins that were due would not differ from the resins that are within the validity period, since none of the two colors analyzed had a $\Delta \mathrm{E}$ above the undesirable values $(3.7 \Delta \mathrm{E})$. What can justify this small variation in the $\Delta \mathrm{E}$ values obtained is that the different batches of the same resin can show color variation after photopolymerisation. ${ }^{[15]}$

The results of this study also showed that, when analyzing the respective types of composite resin, through the spectrophotometer (Table 2), no composite resin tested was similar to the Vita Classical Scale. The Llis DA1 resin was read as A3.5, and the Llis DA2 resin was read as A4. These results were similar to those obtained in the study by Miranda et al., 2018, ${ }^{[9]}$ which verified that resins with nominal A2 shade were classified by spectrophotometry as A4. What can explain this fact is the translucency of the composite resins, which allow the passage of part of the incident light and, consequently, alter the reading of the spectrophotometer, since such equipment was developed to analyze the light that returns of the analyzed object, after the shot of the reading light. ${ }^{[8,9,16]}$

Composite resins come in a wide variety of colors and their use is tied to the patient's tooth color. As some tooth colors are not so common, their syringes remain stored for a longer period of time until they are used in their entirety, and can reach their expiration date, bordering from which there may be changes in resin conversion. ${ }^{[2.6]}$

The resins tested in this study were only a few months beyond the product's validity. Although the color of the resins is a physical property, it is known that mechanical changes may in future alter the qualities of the restorations. ${ }^{[2]}$ This is because the pigments of a resin are inserted in the organic matrix of the resin and the mechanical properties are related to the inorganic matrix. By becoming a polymer, after polymerization, any change that happens is established by many scholars as physical-mechanical changes. ${ }^{[5]}$
According to Garcia et al., 2010, ${ }^{[5]}$ after the period of validity the composite resins can present losses in their performance, as in the degree of conversion, microhardness and increase in roughness. Thus, restorations may undergo compromises when resins are used. ${ }^{[5]}$ It should be clear that it was not the intent of this study, especially after the results, to indicate the use of products out of date, but how these materials has a short validity, from an optical point of view this property is not influenced by the validity established by the manufacturers.

\section{Conclusion}

From the results found in this study we can conclude that:

- The result of this study showed that, regardless of the color tested, the resins tested did not change color, even after they had expired.

- Overdue and expired resins did not change color when correlated to the Vita scale by spectrophotometry.

\section{References}

[1] Obici AC, Sinhoreti MAC, De Goes MF, Consani S, Sobrinho LC. Effect of the photoactivation method on polymerization shrinkage of restorative composites. Oper Dent. 2002; 27: 192-8.

[2] Chaves FO, Farias NC, Medeiros LM, Alonso RC, Di Hipólito V, D'Alpino PH. Mechanical properties of composites as functions of the syringe storage temperature and energy dose. J Appl Oral Sci. 2015 MarApr;23(2):120-8.

[3] Yap AUJ, Lee HK, Sabapathy R. Release of methacrylic acid from dental composites. Dent Mater 2000;16(3):172-9.

[4] Maciel D, Dias AL, Moyzes MR, Ribeiro JCR, Dias SC, Reis AC. Influência do prazo de validade de resinas compostas na resistência à compressão. Arquivos em Odontologia 2005; 41:193-272.

[5] Garcia Lda F, Roselino Lde M, Pires-de-Souza Fde C, Consani S. Evaluation of the conversion degree, microhardness, and surface roughness of composite resins used after their expiration date. Gen Dent. 2010 Nov-Dec;58(6):e262-7.

[6] Ferracane JL, Mitchem JR, Todd R. Wear and marginal breakdown of composites with various degrees of cure. J Dent Res 1997;76(8):1508-16.

[7] Portero PP. Avaliação instrumental da correspondência de cor de resinas compostas em função de escala de referência, tonalidade, composição e espessura. [tese de doutorado]. Araraquara: Faculdade de Odontologia de Araraquara da UNESP; 2009.

[8] Dantas AAR, Florez FLE, Campos EA, Andrade MF, Saad JRC, Oliveira Júnior, OB. Correspondência de cor de diferentes marcas e sistemas de resina composta em relação à escala vitaclassical. RPG Rev Pós Grad 2011;18(1):45-51.

[9] Miranda DA, Marçal YLV, Proba FP, Moreira TKP, Ferraz LN, Aguiar FHB. Color correspondesse of diferente brands and composite resin systems in relation to the Vita Classical scale through spectrophotometry. Dent Oral Craniofac Res 2018: 5(1):1-4.

[10] Douglas RD, Brewer JD. Acceptability of shade differences in metal ceramic crows. J ProsthetDent 1998;79(3):254-60. 
[11] Johnston WM, Kao EC. Assessment of Appearance Match by Visual Observation and Clinical Colorimetry. J Dent Res 1989; 68(5):819-22.

[12] Téo TB, Takahashi MK, Gonzaga CC, Lopes MGK. Avaliação, após clareamento, da alteração de cor de dentes bovinos imersos em soluções com elevado potencial de pigmentação. Rev Sul-Bras Odontol. 2010 Oct-Dec;7(4):401-5.

[13] Seghi RR, Hewlett ER, Kim J. Visual and instrumental colorimetric assessments of small color differences on translucent dental ceramics. J Dent Res. 1989 Dec;68(12):1760-4.
[14] Russell MD, Gulfraz M, Moss BW. In vivo measurement of colour changes in natural teeth. Journalof Oral Rehabilitation 2000; 27: 786-92.

[15] Vieira APSB, Santos TKGL, Carvalho LGA, Patrício CEG, Galvão AKC, Silveira BC. Diferença de cor entre resinas compostas de lotes diferentes de acordo com a escala Vita. Rev. Campo do Saber 2018: 4(5):86-100.

[16] Masotti AS, Onófrio AB, Conceição EM Spohr AM. Uv-vis spectrophotometric direct transmittance analysis of composite resins. Dental materials 2007; 23: 724-30. 